\title{
Fiber type dependent upregulation of human skeletal muscle UCP2 and UCP3 mRNA expression by high-fat diet.
}

Citation for published version (APA):

Schrauwen, P., Hoppeler, H., Billeter, R., Bakker, A. H. F., \& Pendergast, D. (2001). Fiber type dependent upregulation of human skeletal muscle UCP2 and UCP3 mRNA expression by high-fat diet. International Journal of Obesity, 25(4), 449-456. https://doi.org/10.1038/sj.ijo.0801566

Document status and date:

Published: 01/01/2001

DOI:

10.1038/sj.ijo.0801566

Document Version:

Publisher's PDF, also known as Version of record

Document license:

Taverne

Please check the document version of this publication:

- A submitted manuscript is the version of the article upon submission and before peer-review. There can be important differences between the submitted version and the official published version of record.

People interested in the research are advised to contact the author for the final version of the publication, or visit the DOI to the publisher's website.

- The final author version and the galley proof are versions of the publication after peer review.

- The final published version features the final layout of the paper including the volume, issue and page numbers.

Link to publication

\footnotetext{
General rights rights.

- You may freely distribute the URL identifying the publication in the public portal. please follow below link for the End User Agreement:

www.umlib.nl/taverne-license

Take down policy

If you believe that this document breaches copyright please contact us at:

repository@maastrichtuniversity.nl

providing details and we will investigate your claim.
}

Copyright and moral rights for the publications made accessible in the public portal are retained by the authors and/or other copyright owners and it is a condition of accessing publications that users recognise and abide by the legal requirements associated with these

- Users may download and print one copy of any publication from the public portal for the purpose of private study or research.

- You may not further distribute the material or use it for any profit-making activity or commercial gain

If the publication is distributed under the terms of Article $25 \mathrm{fa}$ of the Dutch Copyright Act, indicated by the "Taverne" license above, 


\title{
Fiber type dependent upregulation of human skeletal muscle UCP2 and UCP3 mRNA expression by high-fat diet
}

\author{
P Schrauwen ${ }^{1 *}$, H Hoppeler ${ }^{2}$, R Billeter ${ }^{2}$, AHF Bakker ${ }^{1}$ and DR Pendergast ${ }^{3}$ \\ ${ }^{1}$ Department of Human Biology, Maastricht University, Maastricht, The Netherlands; ${ }^{2}$ Department of Anatomy, University of Bern, \\ Bern, Switzerland; and ${ }^{3}$ Department of Physiology, University of Buffalo, Buffalo, NY, USA
}

OBJECTIVE: To test the hypothesis that consumption of a high-fat diet leads to an increase in UCP mRNA expression in human skeletal muscle. In a group of endurance athletes, with a range in fiber type distribution, we hypothesized that the effect of the high-fat diet on UCP2 and UCP3 mRNA expression is more pronounced in muscle fibers which are known to have a high capacity to shift from carbohydrate to fat oxidation (type IIA fibers).

DESIGN: Ten healthy trained athletes (five males, five females) consumed a low-fat diet (17 \pm 0.9 en\% of fat) and high-fat diet $(41.4 \pm 1.4$ en $\%$ fat) for 4 weeks, separated by a 4 week wash-out period. Muscle biopsies were collected at the end of both dietary periods.

MEASUREMENTS: Using RT-PCR, levels of UCP2 and UCP3 mRNA expression were measured and the percentage of type I, IIA and IIB fibers were determined using the myofibrillar ATPase method in all subjects.

RESULTS: UCP3L mRNA expression tended to be higher on the high-fat diet, an effect which reached significance when only males were considered $(P=0.037)$. Furthermore, diet-induced change in mRNA expression of UCP3T $(r: 0.66, P=0.037)$, UCP3L ( $r: 0.61, P=0.06)$ and UCP2 ( $r: 0.70, P=0.025)$, but not UCP3S, correlated significantly with percentage dietary fat on the high-fat diet. Plasma FFA levels were not different during the two diets. Finally, the percentage of type IIA fibers was positively correlated with the diet-induced change in mRNA expression for UCP2 $(r: 0.7, P=0.03), U C P 3 L(r: 0.73, P=0.016)$ and UCP3T ( $r: 0.68, P=0.03$ ) but not with UCP3S ( $r: 0.06, N S)$.

CONCLUSION: UCP2 and UCP3 mRNAs are upregulated by a high-fat diet. This upregulation is more pronounced in humans with high proportions of type IIA fibers, suggesting a role for UCPs in lipid utilization.

International Journal of Obesity (2001) 25, 449-456

Keywords: dietary fat; uncoupling proteins; metabolism; humans

\section{Introduction}

In rodents, brown adipose tissue plays an important role in thermogenesis, via the activation of an uncoupling protein gene, UCP1. This uncoupling protein gene encodes for a mitochondrial protein carrier, which uncouples respiration from ATP production and stimulates heat production. ${ }^{1}$ UCP1 is expressed in brown adipose tissue only, which is scarce in adult humans and is not thought to play a major role in energy balance. Recently, two additional (human) uncou-

*Correspondence: P Schrauwen, Department of Human Biology, Maastricht University, PO Box 616, 6200 MD Maastricht, The Netherlands.

E-mail: p.schrauwen@hb.unimaas.nl

Received 1 August 2000; revised 16 October 2000;

accepted 6 November 2000 pling proteins, UCP2 ${ }^{2,3}$ and UCP3, ${ }^{4,5}$ were discovered, with high homology to UCP1. In humans, UCP3 is uniquely expressed in skeletal muscle ${ }^{4,5}$ and is a likely candidate to be involved in human energy metabolism. UCP3 is expressed in a long (UCP3L) and a short form (UCP3S), the latter lacking exon 7 , likely resulting in a truncated protein. It is unknown whether this difference is functionally important although this C-terminal region (37 amino acids) is thought to contain a nucleotide binding region. In accordance with a role for UCP3 in human energy metabolism, we recently showed that mRNA expression of UCP3 in Pima Indians was positively correlated with sleeping metabolic rate. ${ }^{6}$

Apart from their role in energy metabolism, suggestions were made for UCP involvement in the metabolism of fatty acids. In rodents, fasting upregulates both skeletal muscle UCP2 $2^{7,8}$ and UCP3 ${ }^{9,10}$ mRNA expression, which is 
in disaccordance with a role for UCPs in energy metabolism. Furthermore, high-fat feeding has been shown to upregulate skeletal muscle UCP3 mRNA expression in rodents, ${ }^{11,12}$ although results are conflicting. ${ }^{13}$ As a possible explanation for the increased UCP expression during fasting and during high-fat diets an elevation of free fatty acid (FFA) levels in plasma and/or an increase in fat oxidation have been proposed. Indeed, it has been shown that elevating FFA, upregulates skeletal muscle UCP3 mRNA expression in rats. ${ }^{14}$ In rats, Samec et $a l^{8,15}$ recently showed that the effect of FFA levels on UCP2 and UCP3 mRNA expression is muscle fiber type dependent. Thus, the upregulation of UCP2 and UCP3 mRNA by FFA levels was much more pronounced in fasttwitch fibers compared to slow-twitch fibers. Lowering FFA levels blunted the increase of UCP2 and UCP3 mRNA in the slow-twitch fibers, but not in the fast-twitch fibers. Since fasttwitch fibers have a higher capacity to switch from glucose oxidation to fat oxidation compared to slow-twitch fibers during fasting or high-fat feeding, they suggested that UCPs might act as regulators of lipid as fuel substrate.

In humans, few data are available on the potential role of UCPs in fat metabolism. Millet et l $^{16}$ showed that a five day hypocaloric diet induced a 2-3-fold increase in skeletal muscle UCP2 and UCP3 mRNA expression in human subjects. Furthermore, a mutation in the UCP3 gene was associated with a decreased fat oxidation capacity. ${ }^{17}$ Finally, Simoneau et al $^{18}$ found that UCP2 protein content was associated with a reduced skeletal muscle lipid utilization. These findings thus suggest a role for UCPs in fat metabolism in humans, either due to the regulation of UCPs by FFA or due to a role of UCPs in handling lipid as a fuel. Suggestions have been made that UCPs are involved in the translocation of the fatty acid anions over the mitochondrial membrane. ${ }^{19}$ In the present study we examined whether the consumption of a high-fat diet increases the expression of UCP mRNA in a population which is known to have a high fat oxidation capacity. We have shown before, that after seven days of a high-fat diet, fat oxidation was increased sufficiently to match fat intake, and this increase in fat oxidation was not accompanied by an increase in plasma FFA levels. ${ }^{20}$ Therefore, an increase in UCP mRNA after prolonged high-fat consumption would suggest a role for UCP in the handling of lipid as a fuel. To test the latter, we examined whether the effect of the high-fat diet on UCP2 and UCP3 mRNA expression is more pronounced in human subjects with high amounts of type IIA muscle fibers, which have a higher capacity to shift from carbohydrate to fat oxidation compared to type I muscle fibers.

\section{Research design and methods Subjects}

Five male and five female runners, who participated in a previous study ${ }^{21}$ were included in this study. Subjects characteristics were as follows (mean \pm s.e.m.): age, $34.1 \pm 2.4 \mathrm{y}$; height, $176 \pm 4.1 \mathrm{~cm}$; weight, $66.2 \pm 4.1 \mathrm{~kg} ; \mathrm{VO}_{2 \max }$
$67.0 \pm 2.7 \mathrm{ml} / \mathrm{kg}$ FFM). The study was approved by the Institutional Review Board on Human Subjects and Experimentation of the University of Buffalo and subjects signed informed consent forms. All subjects were well-trained, healthy and non-smoking athletes with a minimum training of $60 \mathrm{~km} /$ week.

\section{Diet and training}

The subjects were taught to record daily their nutritional intake and their activities. Based on the activity level energy expenditure was calculated. Subjects were prescribed diets based on three-day food intake records, a food preference list and personal consultation. Auto-Nutritionist IV software (First Databank, San Bruno, CA) was used to generate individualized sample menus that they followed. Caloric intake was matched to caloric expenditure on diets consisting of either 16\% (low-fat) or $42 \%$ (high-fat) of total calories from dietary fat. Protein intake was fixed at $15 \%$ of total calories, with the balance of the calories from carbohydrates $(69 \%$ or $43 \%$ ). The subjects were required to keep daily intake and activity records that were evaluated weekly by the dietitians to insure compliance. Each of the diets lasted for 28-31 days and they were separated by 28-31 days of a diet consisting of $32 \%$ fat, $15 \%$ protein and $53 \%$ carbohydrates (washout period). The low-fat diet was always consumed first. Muscle biopsies were taken at the end of the low- and high-fat period.

Training intensity during the three month period of this study was recorded daily and monitored weekly.

\section{Exercise tests}

To control for the circadian rhythms of individual subjects, each runner was tested on the same day of the week and same time of the day on each protocol. Furthermore, females were always tested in the same menstrual cycle phase. For $\mathrm{VO}_{2 \max }$ determination, subjects ran on a level treadmill at a pace of $12 \mathrm{~km} / \mathrm{h}$ for $3 \mathrm{~min}$. The grade on the treadmill was then increased in $2 \%$ increments every 2 min until voluntary exhaustion. Gas exchange was measured by standard open circuit technique (Perkin-Elmer 1200 Multiple Gas Analyzer, Pomona, CA, USA) in the last minute of each successive work rate. Blood was sampled by venapuncture from the antecubital vein after a $3 \mathrm{~h}$ fast. FFA was determined spectrophotometrically by the method of Itaya. ${ }^{22}$

\section{Muscle biopsy and RNA analysis}

Muscle biopsies were taken from the mid-thigh region from M. vastus lateralis according to the technique of Bergström. ${ }^{23}$ The subjects were required to abstain from training or vigorous exercise $24 \mathrm{~h}$ prior to the biopsy. One part of the biopsy was immediately frozen in isopentane cooled with liquid nitrogen and processed for histochemistry. $12 \mu \mathrm{m}$ cryostat cross-sections were processed for the demonstration 
of myofibrillar ATPase according to the technique described in detail by Billeter. ${ }^{24}$ All fiber type counts were obtained from sections treated with acid pre-incubation ( $\mathrm{pH} 4.5)$. We analyzed 3-5 individual sections from each muscle biopsy depending on the size of the biopsy specimens. All fibers that appeared reasonably cross-sectioned (minor to larger fiber axis $>0.5$ ) were counted.

Total RNA was isolated using the acid phenol method of Chomozynski and Sacchi, ${ }^{25}$ with an additional DNAse digestion step with concomitant acid phenol extraction and ethanol precipitation. Integrity of each RNA sample was verified by gel electrophoresis. cDNA was prepared by reverse transcription of total RNA with Superscript Rnase (GIBCO BRL) according to the manufacturer's instructions using random hexamer primers (Böhringer Mannheim, Germany). The cDNA was diluted to $200 \mu \mathrm{l}$ with TE and stored at $-20^{\circ} \mathrm{C}$. $2 \mu \mathrm{l}$ of first-strand cDNA was used for reverse transcription PCR (RT-PCR) in $25 \mu \mathrm{l}$ reactions containing $400 \mu \mathrm{M} d \mathrm{dTP}$, $1 \mu \mathrm{M}$ primers, $1.25 \mathrm{U}^{\text {Taqbead }}{ }^{(i)}$ hot start polymerase (Promega), $1 \times$ PCR buffer and $2.0 \mathrm{mM} \mathrm{MgCl}_{2}$. All primer combinations were designed to span at least one intron to avoid co-amplification of genomic DNA which may contaminate the RNA preparation. The primers used for amplifying cDNA fragments are shown in Table 1. PCR conditions were: $1 \mathrm{~min}$ at $94^{\circ} \mathrm{C}, 45 \mathrm{sec}$ at $57^{\circ} \mathrm{C}$ and $2 \mathrm{~min}$ at $72^{\circ} \mathrm{C}$. For each product, the linear phase of the PCR amplification was tested separately. PCR products were resolved on a $1 \%$ agarose gel containing Gelstar ${ }^{\circledR}$ nucleic acid gel stain (FMC bioproducts) and were quantified by Imagemaster (Pharmacia biotech). Levels of mRNA were expressed as the ratio of signal intensity for the target gene relative to $\beta$-actin and were corrected for the size of the product. All determinations were performed in triplicate.

\section{Statistical analyses}

To compare parameter estimates after the low- and high-fat diet period, Student's $t$-test for paired samples was used. Pearson correlation coefficients were calculated to determine the relationship between selected variables. Data are expressed as means \pm s.d. and $P$ values $<0.05$ are considered significant.

\section{Results}

The expression of UCP3T correlated with the sum of the expression of UCP3L + UCP3S $(r=0.82, P<0.0001)$. The

Table 1 Sequences of PCR primers

\begin{tabular}{lccc}
\hline Gene & Sense primer $\left(5^{\prime}-3^{\prime}\right)$ & Antisense primer $\left(5^{\prime}-3^{\prime}\right)$ & Size of cDNA (bp) \\
\hline UCP2 & gacctatgacctcatcaagg & ataggtgacgaacatcaccacg & 290 \\
UCP3L atggacgcctacagaaccat & tacgaacatcaccacgttcc & 390 \\
UCP3S & atggacgcctacagaaccat & tcaccgctacatcccaggtt & 436 \\
UCP3T & atggacgcctacagaaccat & ctgggccaccatctttatca & 312 \\
$\beta$-actin & actgactacctcatgaagat & cgtcatactcctgcttgctgat & 535 \\
\hline
\end{tabular}

ratio of UCP3S to UCP3L mRNA expression did not correlate with any of the measured variables. At baseline (low-fat diet) UCP3L mRNA expression was negatively correlated with age (Figure $1 ; r=0.71, P=0.022$ ) and UCP2 mRNA expression was negatively correlated with body weight (Figure 2, $r=0.67, P=0.04)$. There were no other correlations between UCP2 or UCP3 mRNA expression and age, body weight, body mass index (BMI), percentage body fat and $\mathrm{VO}_{2 \max }$.

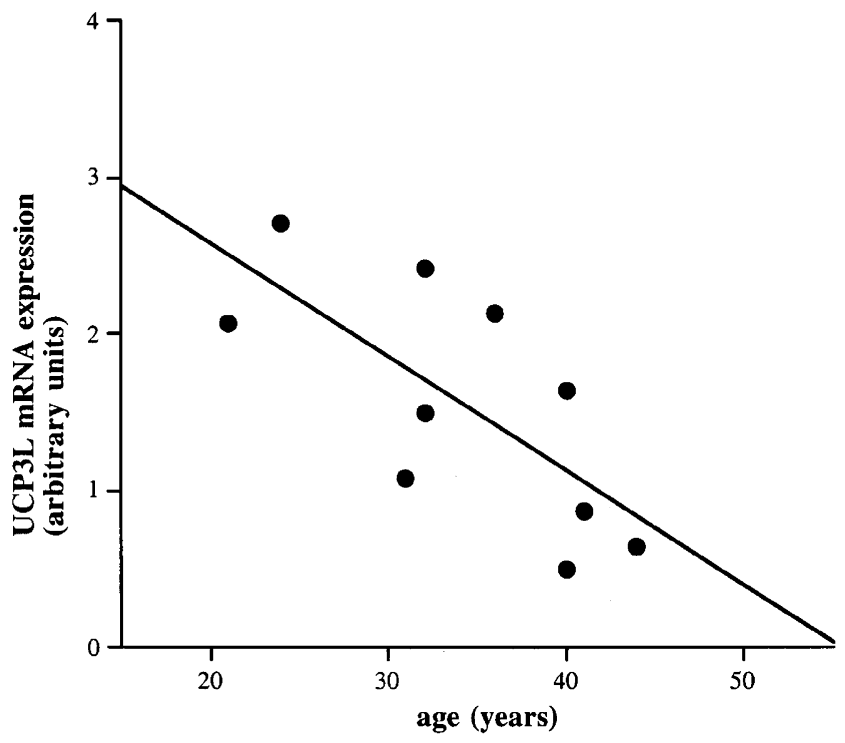

Figure 1 Relationship between UCP3L mRNA expression (ratio with $\beta$ actin) and age $(r=0.71, P=0.022)$. Data represent the mean of three RT-PCR determinations.

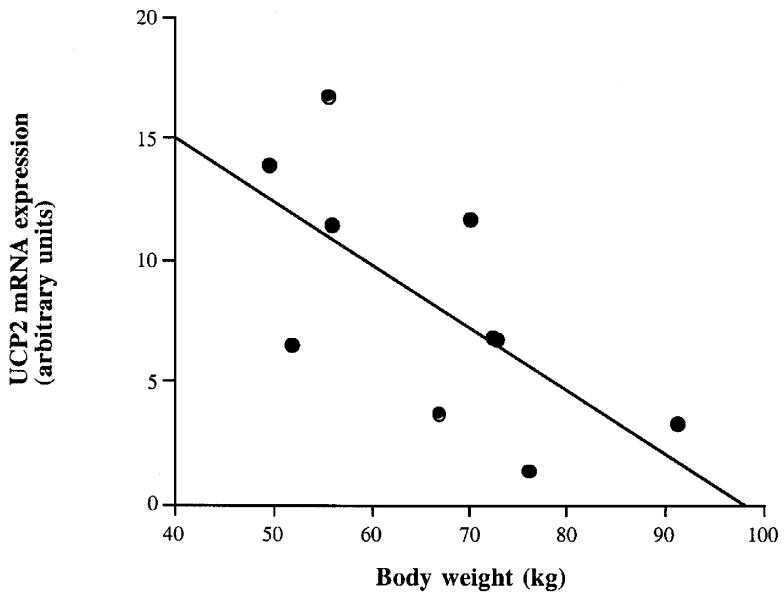

Figure 2 Relationship between UCP2 mRNA expression (ratio with $\beta$ actin) and body weight $(r=0.67, P=0.04)$. Data represent the mean of three RT-PCR determinations. 
Effect of the high-fat diet on UCP2 and UCP3 mRNA expression

On average, subjects consumed $17.2 \pm 0.9 \%$ of the total calories as fat on the low-fat diet and $41.4 \pm 1.4 \%$ on the high-fat diet. $\mathrm{VO}_{2 \max }$ was not different between the low-fat and high-fat diet $(67.0 \pm 2.7 v s 67.5 \pm 2.8 \mathrm{ml} / \mathrm{kg}$ FFM), indicating that training intensity/duration was not altered during the study. Energy intake was significantly higher on the high-fat diet compared to the low-fat diet $(2804 \pm 165 \mathrm{vs}$ $2081 \pm 156 \mathrm{kcal}, P=0.0008)$. This resulted in a significant, but small (less than 1.5\%) increase in body weight on the high-fat diet compared to the low-fat diet $(67.2 \pm 4.2 \mathrm{vs}$ $66.2 \pm 4.1 \mathrm{~kg}, P=0.017)$. Plasma FFA $(1.3 \pm 0.1$ vs $1.2 \pm$ $0.1 \mathrm{mM})$ and triglyceride $(47.0 \pm 5.6 v s 44.4 \pm 4.0 \mathrm{mg} / \mathrm{dl})$ concentrations were not different between low- and high-fat diet.

UCP3L mRNA expression tended to be higher after the high-fat diet compared to the low-fat diet (Figure 3; $2.5 \pm 0.6$ vs $1.5 \pm 0.2, P=0.08)$. When only male subjects were considered, the high-fat diet significantly increased UCP3L mRNA 2.2-fold ( $3.8 \pm 0.8$ vs $1.7 \pm 0.4, P=0.037)$. However, UCP3S, UCP3T and UCP2 mRNA expression was not significantly different between the high-fat and low-fat diet. However, since there was a wide range in percentage of dietary fat on the high-fat diet (35 to 49 en\% as fat), we hypothesized that the high-fat diet was not 'fat' enough in all subjects. Therefore, we examined whether the effect of the switch from low-fat to high-fat diet on UCP expression was related to the 'severity' of the high-fat diet. Interestingly, we found that the diet-induced changes (delta) in mRNA expression of UCP3T (Figure $4 \mathrm{a} ; r=0.66, P=0.037$ ), UCP3L (Figure $4 \mathrm{~b}$; $r=0.61, P=0.06$ ) and UCP2 (Figure $4 \mathrm{~d} ; r=0.70, P=0.025$ ),

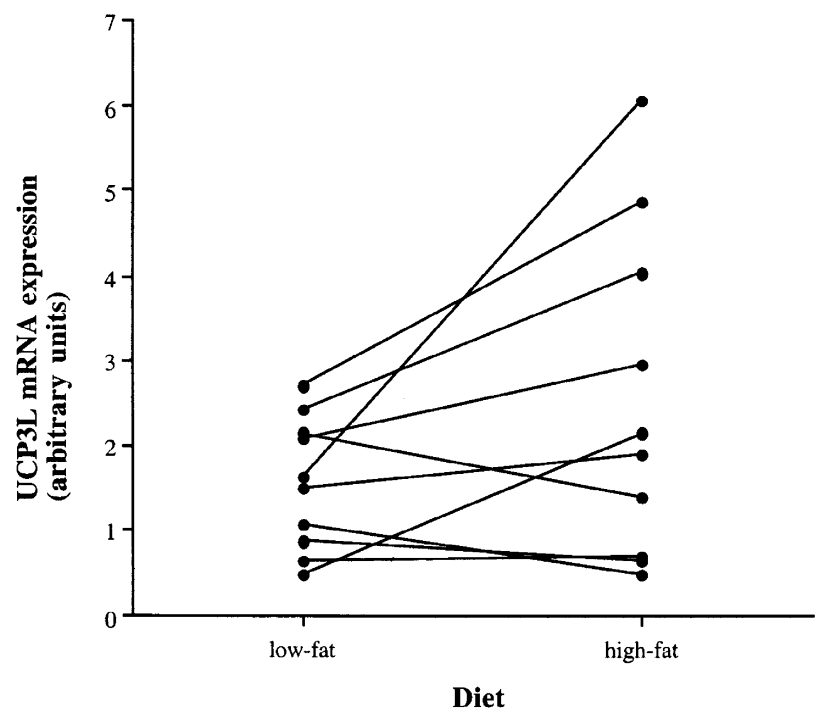

Figure 3 UCP3L mRNA expression (ratio with $\beta$-actin) during lowfat and high-fat diet. Data represent the mean of three RT-PCR determinations. but not UCP3S (Figure 4c), correlated significantly with the percentage dietary fat on the high-fat diet. The diet-induced change in body weight and/or energy intake had no effect on the expression of UCP2 and UCP3 mRNA.

\section{UCP expression and muscle fiber types}

It has been suggested that the expression of UCP is muscle fiber type specific. At baseline, we found no correlations between any of the UCP isoforms and percentage of type I, IIA or IIB fibers. However, on the high-fat diet, UCP3S mRNA (Figure 5c; $r=0.83, P=0.0031$ ) and UCP3T (Figure 5a; $r=0.74, P=0.016)$ mRNA expression were positively correlated with percentage of type IIA fibers, whereas this correlation tended to be significant for UCP3L (Figure $5 \mathrm{~b} ; r=0.57$, $P=0.09$ ). Furthermore, the diet-induced change in mRNA expression was also positively correlated with the percentage of type IIA fibers for UCP2 $(r=0.7, P=0.03)$, UCP3L $(r=0.73$, $P=0.016)$ and UCP3T $(r=0.68, P=0.03)$ but not for UCP3S $(r=0.06, \mathrm{NS})$.

\section{Discussion}

Uncoupling proteins 2 and 3 are recently discovered human uncoupling proteins, with a suggested involvement in energy metabolism and obesity (for reviews see references (26 and 27)). The finding that UCP2 and UCP3 mRNAs are upregulated by FFA has led to the hypothesis that these UCPs are involved in the metabolism of fatty acids. In the present study we examined the effect of the consumption of a highfat diet (without changes in FFA levels) on UCP mRNA expression in human subjects. We found a tendency for higher levels of UCP3L mRNA expression after four weeks of a high-fat diet. Considering male subjects only, UCP3L mRNA was significantly higher on the high-fat diet compared to the low-fat diet. Further examination revealed that the actual percentage of calories derived from fat was not exactly $41 \%$ in all subjects, but ranged from $35-49 \%$. Importantly, the change in UCP2, UCP3L and UCP3T mRNA expression was correlated with this percentage of calories derived from fat on the high-fat diet. In other words, the increase in UCP mRNA expression depended on the 'severity' of the high-fat diet. We therefore feel justified to conclude that high-fat feeding upregulates the expression of all uncoupling proteins in skeletal muscle except for the short isoform of UCP3. These findings are in accordance with findings in rodents, showing increased UCP3 mRNA levels after high-fat feeding. ${ }^{11,12}$

The mechanism by which high-fat feeding (and fasting) upregulates UCP2 and UCP3 mRNA is not yet known. Suggestions have been made that FFA, which are increased during fasting and high-fat feeding, are responsible for the increase in UCP mRNA. To test this hypothesis, Weigle et al ${ }^{14}$ elevated plasma FFA levels in rats, resulting in UCP3 mRNA levels which were similar to those induced by fasting. Furthermore, Boss et $a l^{28}$ showed that plasma FFA concentra- 

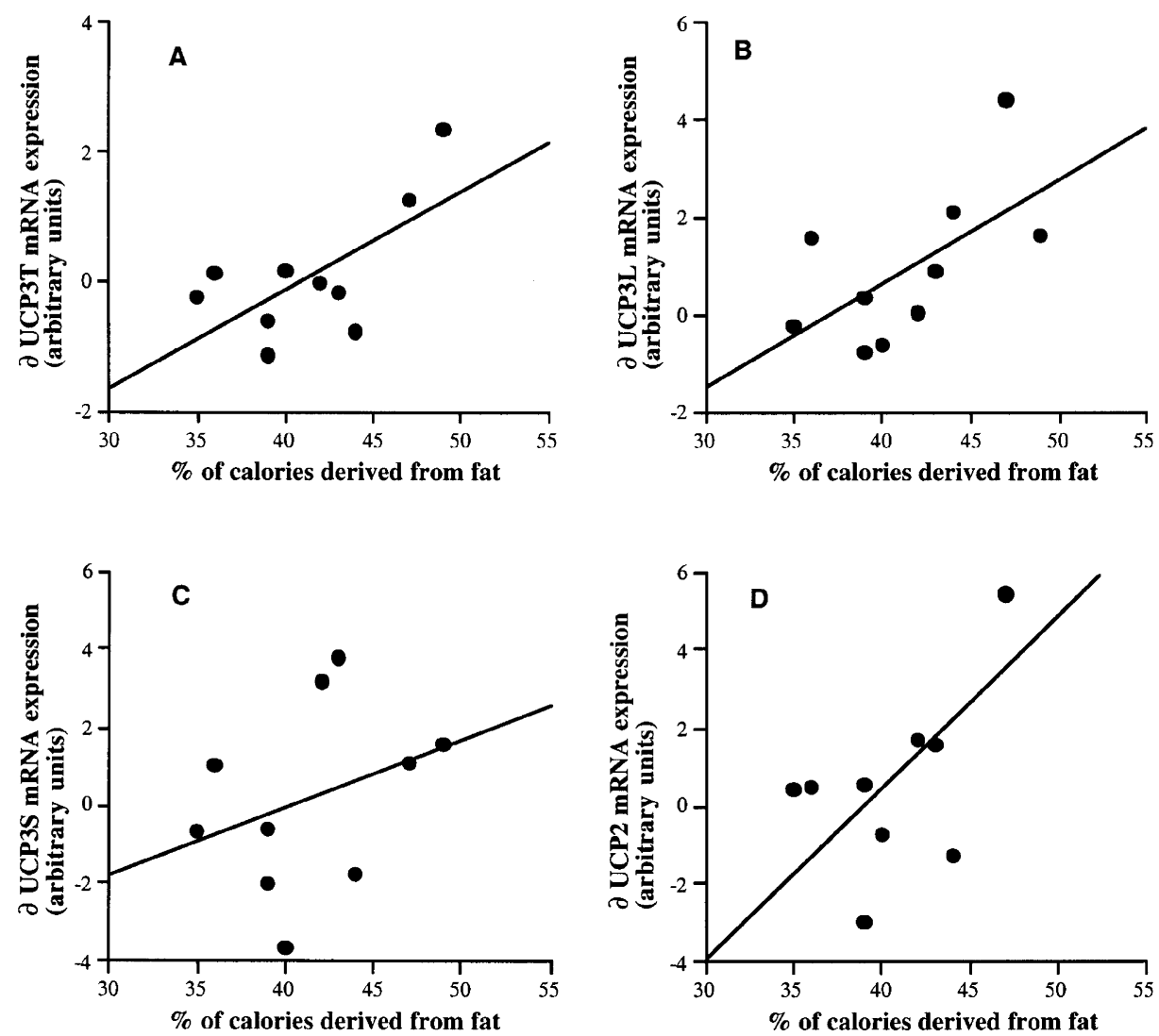

Figure 4 Relationship between delta ( $=$ mRNA expression on high-fat minus low-fat diet) UCP3T $(A, r=0.66, P=0.037), U C P 3 L(B, r=0.61, P=0.06$ ), UCP3S $(C, r=0.33, P=0.35)$ and UCP2 $(D, r=0.70, P=0.025)$ mRNA expression and percentage of calories derived from fat on the high-fat diet. Data represent the mean of three RT-PCR determinations.

tions were positively correlated with the expression of UCP3 mRNA. Taken together, these studies provide some evidence for a role of FFA in the regulation of UCPs. However, during fasting and/or high-fat feeding, elevated FFA levels are also accompanied by an increased fat oxidation and thus the increase in UCP expression during fasting and/or high-fat feeding could also be related to an increase in fat oxidation. Although we did not measure fat oxidation in the present study, our results suggest a relationship between UCP expression and fat oxidation. Firstly, the upregulation of UCP in skeletal muscle in this study was not explained by an increase in FFA levels. Secondly, we have shown before that in humans, fat oxidation is increased after seven days on a high-fat diet and that this increased fat oxidation is not accompanied by an increase in plasma FFA levels. ${ }^{20,29,30}$ Finally, in the present study UCP2 and UCP3 mRNA levels on the high-fat diet, as well as the diet-induced changes in UCP2, UCP3L and UCP3T mRNA were correlated with the amount of type IIA fibers. Type IIA fibers are characterized by a high capacity for both carbohydrate and fat oxidation ${ }^{31}$ and it can be suggested that these fibers have a high capacity to switch from carbohydrate to fat oxidation when a high-fat diet is consumed. Therefore, these data, together with data from Samec et $a l^{8,15}$ who showed similar findings in rats, are in accordance with a role for UCPs in the metabolism of fatty acids, but further studies are clearly needed to explore the physiological function of human uncoupling proteins.

The mechanism by which UCPs could be involved in the metabolism of fatty acids is still unknown. Suggestions have been made that UCPs can exert their uncoupling effect by being involved in fatty acid cycling across the inner mitochondrial matrix. ${ }^{32}$ On the matrix side of the mitochondrial membrane, UCPs could be involved in the translocation of the fatty acid anions to the cytosolic side of the membrane. Here the fatty acid anion is protonated and 'flip-flops' rapidly back to the matrix side, since neutral fatty acids can easily 'flip-flop' across the membrane. In this way, the proton gradient is lowered and heat is produced. At the same time, UCPs could then be involved in translocating an excessive amount of fatty acid anions out of the mitochondria, as suggested previously. ${ }^{18}$ A role for UCPs in translocating fatty acid anions over the inner mitochondrial membrane, would also be in accordance with a role for UCPs in energy metabolism. We previously reported that mutations in the UCP2 and UCP3 gene were associated with sleeping metabolic rate in Pima Indians. ${ }^{33}$ Furthermore, we 

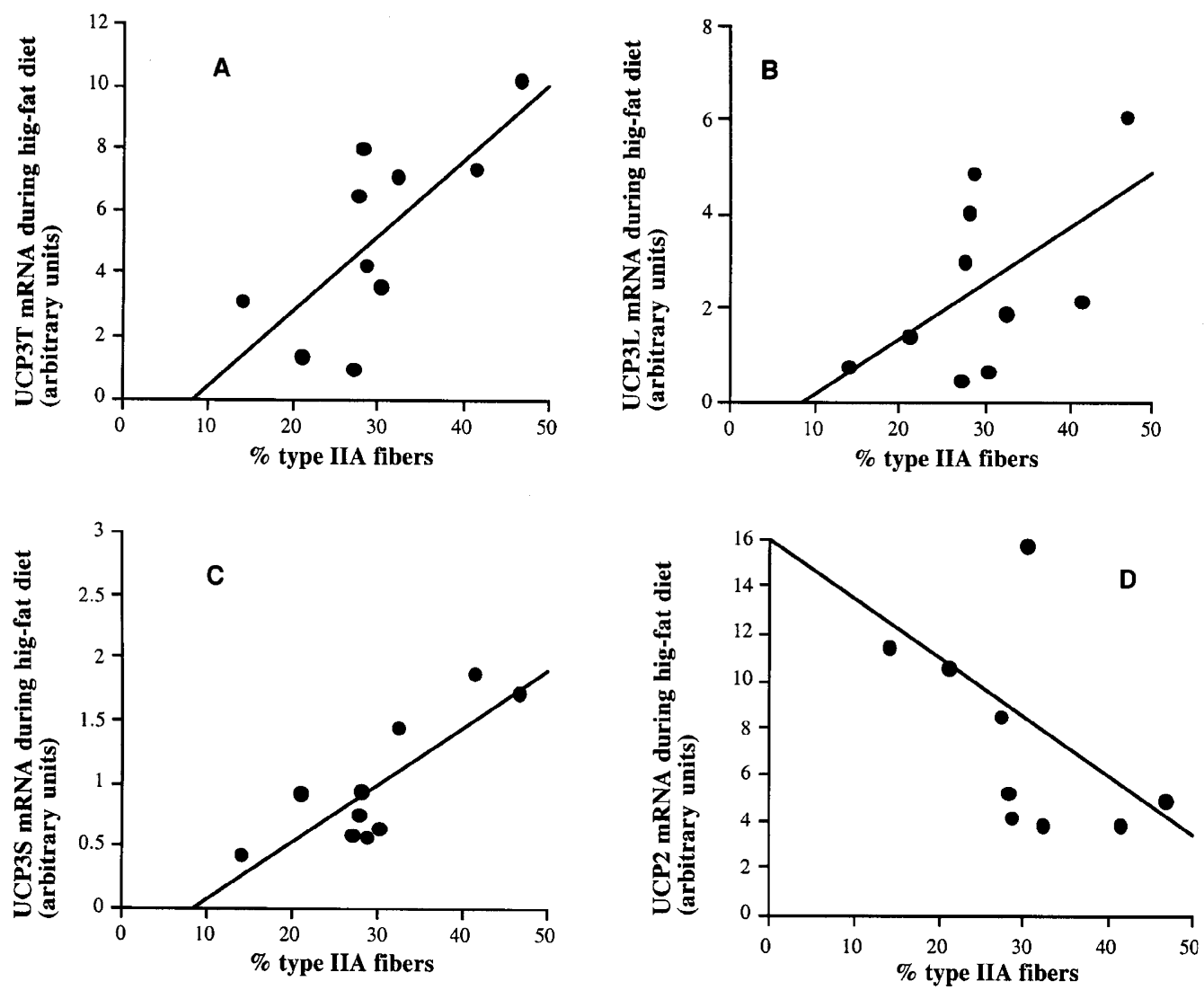

Figure 5 Relationship between UCP3T ( $A, r=0.74, P=0.016)$, UCP3L $(B, r=0.57, P=0.09)$, UCP3S $(C, r=0.83, P=0.003)$ and UCP2 (D, $r=0.046$, $P=0.18$ ) mRNA expression (ratio with $\beta$-actin) and percentage type IIA fibers. Data represent the mean of three RT-PCR determinations.

reported that UCP3 mRNA expression was positively correlated with sleeping metabolic rate in the same population. ${ }^{6}$ In the present study, we did not measure basal energy expenditure. However, body weight increased by, on average, $1 \mathrm{~kg}$, whereas energy intake was increased by, on average, $\sim 720 \mathrm{kcal} /$ day $(+35 \%)$. With a $35 \%$ increase in energy intake a more pronounced increase in body weight $(>2.5 \mathrm{~kg})$ would have been expected. Thus the induction of UCPs on a high-fat diet might be helpful in expending extra calories. However, future studies are necessary to examine whether the capacity to induce UCPs on a high-fat diet is accompanied by an increased (resting) metabolic rate and whether UCPs could play a role in the susceptibility to diet-induced obesity.

On the low-fat diet, we found a negative correlation between UCP3L mRNA and age, which could not be explained by any of the other variables measured. This is in agreement with a role for UCP3 in energy expenditure and/or fat metabolism, since it has been shown that both $\mathrm{BMR}^{34}$ and basal fat oxidation ${ }^{35}$ are decreased by aging. Furthermore, Yamashita et $a l^{36}$ showed that the induction of uncoupling proteins during cold exposure was diminished in old compared to young rats. It is therefore possible that a decreased expression of uncoupling proteins could explain part of the decrease in BMR and fat oxidation with age and thus contribute to the age-related development of obesity. However, more studies are necessary to provide evidence for an age-related decline in UCP3 mRNA.

In this study, only endurance-trained subjects participated, who are known to have a good fat oxidation capacity. This might have influenced the outcome of the study. Endurance trained athletes are characterized by a higher proportions of type I fibers, when compared to sedentary subjects. Based on our results, one could expect that the increase in UCP2 and UCP3 mRNA on a high-fat diet is more pronounced in sedentary subjects. Furthermore, we recently showed that trained subjects have lower levels of skeletal muscle UCP2 and UCP3 mRNA when compared to untrained subjects, but only after correction for the difference in mitochondrial density between those two groups. ${ }^{37}$ Thus, the absolute value of UCP mRNAs was not different between trained and untrained subjects. In the present study, training intensity and duration were kept constant over the entire study period, as indicated by the unaltered $\mathrm{VO}_{2 \max }$ on the low- and high-fat diet. Furthermore, mitochondrial content was not changed by the diet, as we showed before. ${ }^{38}$ It is therefore not likely that the effect of dietary fat intake 
is different in trained compared to untrained subjects, if one takes into account their differences in fiber type composition.

In conclusion, UCP2 and UCP3 mRNA expression are upregulated by high-fat diet. This upregulation is more pronounced in humans with high amounts of type IIA fibers, characterized by a high capacity to switch from glucose to fat oxidation, suggesting a role for UCPs in lipid utilization.

\section{Acknowledgements}

Dr Schrauwen is supported by a grant from the Netherlands Organisation for Scientific Research (NWO).

\section{References}

1 Ricquier D, Casteilla L, Bouillaud F. Molecular studies of the uncoupling protein. FASEB J 1991; 5: 2237-2242.

2 Fleury C, Neverova M, Collins S, Raimbault S, Champigny O, Levi-Meyrueis C, Bouillaud F, Seldin MF, Surwit RS, Ricquier D. Uncoupling protein-2: a novel gene linked to obesity and hyperinsulinemia. Nature Genet 1997; 15: 269-273.

3 Gimeno RE, Dembski M, Weng X, Deng N, Shyjan AW, Gimeno CJ, Iris F, Ellis SJ, Woolf EA, Tartaglia LA. Cloning and characterization of an uncoupling protein homolog: a potential molecular mediator of human thermogenesis. Diabetes 1997; 46: 900-906.

4 Boss O, Samec S, Paoloni-Giacobino A, Rossier C, Dulloo A Seydoux J, Muzzin P, Giacobino J-P. Uncoupling protein-3: a new member of the mitochondrial carrier family with tissuespecific expression. FEBS lett 1997; 408: 39-42.

5 Vidal-Puig A, Solanes G, Grujic D, Flier JS, Lowell BB. UCP3: an uncoupling protein homologue expressed preferentially and abundantly in skeletal muscle and brown adipose tissue. Biochem Biophys Res Commun 1997; 235: 79-82.

6 Schrauwen P, Xia J, Bogardus C, Pratley R, Ravussin E. Skeletal muscle UCP3 expression is a determinant of energy expenditure in Pima Indians. Diabetes 1999; 48: 146-149.

7 Boss O, Samec S, Dulloo A, Seydoux J, Muzzin P, Giacobino J-P. Tissue-dependent upregulation of rat uncoupling protein-2 expression in response to fasting or cold. FEBS lett 1997; 412: $111-114$.

8 Samec S, Seydoux J, Dulloo AG. Interorgan signaling between adipose tissue metabolism and skeletal muscle uncoupling protein homologs: is there a role for circulating free fatty acids? Diabetes 1998; 47: $1693-1698$.

9 Gong D-W, He Y, Karas M, Reitman M. Uncoupling protein-3 is a mediator of thermogenesis regulated by thyroid hormone, $\beta 3$ adrenergic agonists, and leptin. J Biol Chem 1997; 272: 24129 24132.

10 Boss O, Samec S, Kühne F, Bijlenga P, Assimacopoulos-Jeannet F, Seydoux J, Giacobino J-P, Muzzin P. Uncoupling protein-3 expression in rodent skeletal muscle is modulated by food intake but not by changes in environmental temperature. J Biol Chem 1998; 273: $5-8$.

11 Matsuda J, Hosoda K, Itoh H, Son C, Doi K, Tanaka T, Fukunaga Y, Inoue $G$, Nishimura $H$, Yoshimasa $Y$. Cloning of rat uncoupling protein-3 and uncoupling protein-2 cDNAs: their gene expression in rats fed high-fat diet. FEBS lett 1997; 418: 200-204.

12 Gong D-W, He Y, Reitman ML. Genomic organization and regulation by dietary fat of the uncoupling protein 3 and 2 genes Biochem Biophys Res Commun 1999; 256: 27-32.

13 Surwit RS, Wang S, Petro AE, Sanchis D, Raimbault S, Ricquier D, Collins S. Diet-induced changes in uncoupling proteins in obesity-prone and obesity-resistant strains of mice. Proc Natl Acad Sci USA 1998; 95: 4061 - 4065.
14 Weigle DS, Selfridge LE, Schwartz MW, Seeley RJ, Cummings DE, Havel PJ, Kuijper JL, Bertrande Rio H. Elevated free fatty acids induce uncoupling protein 3 expression in muscle. A potential explanation for the effect of fasting. Diabetes 1998; 47: 298-302.

15 Samec S, Seydoux J, Dulloo AG. Role of UCP homoloques in skeletal muscles and brown adipose tissue: mediators of thermogenesis or regulators of lipids as fuel substrate? FASEB J 1998; 12: $715-724$.

16 Millet L, Vidal H, Andreelli F, Larrouy D, Riou J-P, Ricquier D, Laville $\mathrm{M}$, Langin D. Increased uncoupling protein-2 and -3 mRNA expression during fasting in obese and lean humans. $J$ Clin Invest 1997; 100: $2665-2670$.

17 Argyropoulos G, Brown AM, Willi SM, Zhu J, He Y, Reitman M, Geveo SM, Spruill I, Garvey WT. Effects of mutations in the human uncoupling protein 3 gene on the respiratory quotient and fat oxidation in severe obesity and type 2 diabetes. J Clin Invest 1998; 102: $1345-1351$.

18 Simoneau JA, Kelley DE, Neverova M, Warden CH. Overexpression of muscle uncoupling protein 2 content in human obesity associates with reduced skeletal muscle lipid utilization. FASEB J 1998; 12: 1739 - 1745.

19 Jaburek M, Varecha M, Gimeno RE, Dembski M, Jezek P, Zhang M, Burn P, Tartaglia LA, Garlid KD. Transport function and regulation of mitochondrial uncoupling proteins 2 and 3. J Biol Chem 1999; 274: 26003-26007.

20 Schrauwen P, Marken Lichtenbelt WDv, Saris WHM, Westerterp KR. Changes in fat oxidation in response to a high-fat diet. Am J Clin Nutr 1997; 66: 276-282.

21 Leddy J, Horvath P, Rowland J, Pendergast D. Effect of a high or a low fat diet on cardiovascular risk factors in male and female runners. Med Sci Sports Exerc 1997; 29: 17-25.

22 Itaya K. A more sensitive and stable colorimetric determination of free fatty acids in blood. J Lipid Res 1977; 18: 663-665.

23 Bergstrom J, Hermansen L, Hultman E, Saltin B. Diet, muscle glycogen and physical performance. Acta Physiol Scand 1967; 71: $140-150$.

24 Billeter R, Weber H, Lutz H, Howald H, Eppenberger HM, Jenni E. Myosin types in human skeletal muscle fibers. Histochemistry 1980; 65: 249-259.

25 Chomozynski P, Sacchi N. Single-step method of RNA isolation by acid guanidinium thiocyanate-phenol-chloroform extraction. Anal Biochem 1987; 162: 156-159.

26 Boss O, Muzzin P, Giacobino J-P. The uncoupling proteins, a review. Eur J Endocrinology 1998; 139: 1-9.

27 Schrauwen P, Walder K, Ravussin E. Human uncoupling proteins and obesity. Obes Res 1999; 7: $97-105$.

28 Boss O, Bobbioni-Harsch E, Assimacopoulos-Jeannet F, Muzzin P, Munger R, Giacobino J-P, Golay A. Uncoupling protein-3 expression in skeletal muscle and free fatty acids in obesity. Lancet 1998; 351: 1933.

29 Schrauwen P, Marken Lichtenbelt WDv, Saris WHM, Westerterp KR. Fat balance in obese subjects: role of glycogen stores. $\mathrm{Am} \mathrm{J}$ Physiol 1998; 274: E1027 - 1033.

30 Schrauwen P, Wagenmakers AJM, Marken Lichtenbelt WDv, Saris WHM, Westerterp KR. Increase in fat oxidation on a high-fat diet is accompanied by an increase in triglyceride-derived fatty acid oxidation. Diabetes 2000; 49: 640-646.

31 Barnard RJ, Edgerton VR, Furukawa T, Peter JB. Histochemical, biochemical, and contractile properties of red, white, and intermediate fibers. Am J Physiol 1971; 220: 410-414.

32 Garlid KD, Orosz DE, Modriansky M, Vassanelli S, Jezek P. On the mechanism of fatty acid-induced proton transport by mitochondrial uncoupling protein. J Biol Chem 1996; 271: 2615-2620.

33 Walder K, Norman RA, Hanson RL, Schrauwen P, Neverova M, Jenkinson CP, Easlick J, Warden CH, Pecqueur C, Raimbault S. Association between uncoupling protein polymorphisms (UCP2UCP3) and energy metabolism/obesity in Pima Indians. Hum Mol Genet 1998; 7: $1431-1435$

34 Vaughan L, Zurlo F, Ravussin E. Aging and energy expenditure. Am I Clin Nutr 1991; 53: 821 -825. 
35 Rising R, Tataranni PA, Snitker S, Ravussin E. Decreased ratio of fat to carbohydrate oxidation with increasing age in Pima Indians. J Am Coll Nutr 1996; 15: 309-312.

36 Yamashita H, Sato Y, Mori N. Difference in induction of uncoupling protein genes in adipose tissues between young and old rats during cold exposure. FEBS Lett 1999; 458: 157-161.
37 Schrauwen P, Troost FJ, Xia J, Ravussin E, Saris WHM. Skeletal muscle UCP3 expression in trained and untrained male subjects. Int J Obes Relat Metab Disord 1999; 23: 966-972.

38 Hoppeler H, Billeter R, Horvath PJ, Leddy JJ, Pendergast DR. Muscle structure with low- and high-fat diets in well-trained male runners. Int J Sports Med 1999; 20: 522-526. 